\title{
Antimicrobial Activity of Lactoperoxidase System Incorporated into Cross-Linked Alginate Films
}

\author{
FATIH Y.G. YeNER, Figen KoREL, AND AHMET YeMENICIOĞLU
}

\begin{abstract}
In this study, the antimicrobial effect of lactoperoxidase (LPS) incorporated alginate films was investigated on Escherichia coli (NRRL B-3008), Listeria innocua (NRRL B-33314), and Pseudomonas fluorescens (NRRL B-253) in presence of different concentrations of $\mathrm{H}_{2} \mathrm{O}_{2}(0.2,0.4$, and $0.8 \mathrm{mM})$ and $\mathrm{KSCN}(1,2$, and $4 \mathrm{mM})$. The incorporation of $70 \mathrm{nmol} \mathrm{ABTS} / \mathrm{min} / \mathrm{cm}^{2}$ LPS into alginate films gave 0.66 to $0.85 \mathrm{nmol} \mathrm{ABTS} / \mathrm{min} / \mathrm{cm}^{2}$ enzyme activity at 0.2 to $0.8 \mathrm{mM} \mathrm{H}_{2} \mathrm{O}_{2}$ concentration range. The antimicrobial activity of LPS system on target bacteria changed according to the concentrations of $\mathrm{KSCN}$ and $\mathrm{H}_{2} \mathrm{O}_{2}$. The growth of all tested bacteria was prevented for a 6-h period by applying LPS system in presence of 0.4 or $0.8 \mathrm{mM} \mathrm{H}_{2} \mathrm{O}_{2}$ and $4 \mathrm{mM} \mathrm{KSCN}$. At $0.8 \mathrm{mM} \mathrm{H}_{2} \mathrm{O}_{2}$ and $4 \mathrm{mM}$ KSCN, the LPS system also inhibited growth of $L$. innocua and $P$. fluorescens for a 24-h incubation period, whereas $E$. coli growth could not be inhibited for $24 \mathrm{~h}$ under these conditions. At $0.2 \mathrm{mM} \mathrm{H}_{2} \mathrm{O}_{2}$ and 1 to $4 \mathrm{mM} \mathrm{KSCN}$, a considerable inhibitory effect was obtained only on P. fluorescens. The decreasing order of the resistance of studied bacteria to LPS system is as follows: E. coli, L. innocua, and P. fluorescens. The developed antimicrobial system has a good potential for use in meat, poultry, and seafood since alginate coatings are already used in these products. Further studies are needed to test the LPS incorporated edible films in real food systems.

Keywords: alginate, antimicrobial packaging, edible films, lactoperoxidase
\end{abstract}

\section{Introduction}

A ntimicrobial edible films and coatings have received attention since they have a good potential to delay microbial spoilage of food and to reduce the risk of surface contamination of food by pathogenic microorganisms (Quattara and others 2000; Cagri and others 2002; Eswaranandam and others 2004). Due to their greater acceptance by the growing "natural foods" market, incorporation of biopreservatives, especially bacteriocins and antimicrobial enzymes, and plant extracts into edible films have gained significant interest in the food industry (Hoover and Steenson 1993; Dean and Zottola 1996; Delves-Broughton and others 1998; Han 2000).

Lactoperoxidase (LPS) system is considered for use in food packaging since it has a broad antimicrobial spectrum. The enzyme shows bactericidal effect on Gram (-) bacteria and bacteriostatic effect on Gram (+) bacteria (Seifu and others 2005). Also, it has antifungal (Jacob and others 2000) and antiviral (Pakkanen and Aalto 1997; Seifu and others 2005) activities. LPS is an enzyme found in the milk, saliva, and tear secreted in mammary, salivary, and lachrymal glands of mammals, respectively (Wolfson and Sumner 1993). The LPS system consists of 3 components: LPS, thiocyanate, and hydrogen peroxide $\left(\mathrm{H}_{2} \mathrm{O}_{2}\right)$. The enzyme catalyzes the oxidation of thiocyanate $\left(\mathrm{SCN}^{-}\right)$by use of $\mathrm{H}_{2} \mathrm{O}_{2}$ and generates intermediate antimicrobial products such as hypothiocyanite $\left(\mathrm{OSCN}^{-}\right)$and hypothiocyanous acid (HOSCN). These highly reactive products inhibit microorganisms by the oxidation of sulphydryl $(-\mathrm{SH})$ groups in their enzyme systems and proteins (Kussendrager and van Hooijdonk 2000). The structural damage of microbial cytoplasmic membranes by oxidation of $-\mathrm{SH}$ groups is reported as the principal

MS 20080157 Submitted 2/28/2008, Accepted 11/3/2008. Author Yener is with Biotechnology and Bioengineering Program, and authors Korel and Yemenicioğlu are with Food Engineering Dept., Faculty of Engineering, Izmir Inst. of Technology 35430, Urla, Izmir, Turkey. Direct inquiries to author Korel (E-mail: figenkorel@iyte.edu.tr). reason that causes the death of microbial cells (Reiter and Harnulv 1984; Kussendrager and van Hooijdonk 2000).

In the literature, there are different studies related to antimicrobial potential of LPS system against major food pathogenic bacteria. In these studies, antimicrobial activity of soluble LPS and its components has been tested against Listeria monocytogenes, Staphylococcus aureus, E. coli, Brucella melitensis, and Salmonella enteritidis (Kennedy and others 2000; Seifu and others 2004; Touch and others 2004). The soluble enzyme has also been tested in different food systems to improve microbial quality of milk, cheese (Seifu and others 2004, 2005), meat, and vegetable products (Kennedy and others 2000; Elliot and others 2004; Touch and others 2004). The concept of using LPS system in antimicrobial packaging is new. In fact, the LPS and its components have only been incorporated into edible whey protein films (Min and Krochta 2005; Min and others 2005a, 2005b). Recently, in our laboratories, the LPS has also been incorporated into alginate films. The enzyme incorporated into these edible films bound and immobilized effectively onto films following cross-linking and it shows appropriate stability and activity at a broad temperature and $\mathrm{pH}$ range (Mecitoğlu and Yemenicioğlu 2007). In this study, the antimicrobial activity of LPS incorporated into alginate films and its components has been tested on different bacteria including E. coli, Listeria innocua, and Pseudomonas fluorescens. The specific objectives of this research were to determine the effective concentrations of LPS components against the test bacteria and to test the resistance of different bacteria against the developed antimicrobial system supposed to be used in food coating applications.

\section{Materials and Methods}

\section{Materials}

Toyopearl sulphopropyl (SP) cation-exchanger (SP-550C, fast flow, size: $100 \mu \mathrm{m}$ ) was purchased from Supelco (Bellefonte, Pa., U.S.A.). Dialysis tubes (cut off: $12000 \mathrm{MW}$ ), dextran (from 
Leuconostoc mesenteroides, 73.200 MW), ABTS (2,2-azino-bis-(3ethylbenz-thiazoline-6-sulfonic acid)), and the sodium salt of alginic acid (from Macrocystis pyrifera, viscosity of $2 \%$ solution at $25^{\circ} \mathrm{C}$ is $3500 \mathrm{cp}$ ) were obtained from Sigma Chem. Co. (St. Louis, Mo., U.S.A.). Rennet was purchased from ICN Biomedicals Inc. (Aurora, Ohio, U.S.A.). Nutrient agar and nutrient broth were obtained from Fluka (Spain). The microorganisms, E. coli (NRRL B3008), L. innocua (NRRL B-33314), and P. fluorescens (NRRL B-253), were supplied from U.S. Department of Agriculture (USDA), Microbial Genomics and Bioprocessing Research Unit (Peoria, Ill., U.S.A.).

\section{Partial purification and preparation of LPS}

The partial purification of LPS from bovine whey was conducted with column chromatography by minor modification of the method of Ye and others (2000). In this method, the LPS was produced from rennet whey of skimmed milk using Toyopearl sulphopropyl (SP) cation-exchange column $(11.5 \times 2.8 \mathrm{~cm})$. The column was equilibrated with $0.05 \mathrm{M}$ sodium phosphate buffer at $\mathrm{pH} 6.5$, washed with $500 \mathrm{~mL}$ of the same buffer, and then eluted with a linear gradient of $600 \mathrm{~mL}$ of 0 to $0.55 \mathrm{M} \mathrm{NaCl}$ (prepared in the sodium phosphate buffer). The LPS active fractions eluted between 0.3 and $0.4 \mathrm{M} \mathrm{NaCl}$ concentration were detected qualitatively by using the reaction mixture given in soluble enzyme activity determination.

The enzyme was prepared according to the method of Mecitoğlu and Yemenicioğlu (2007). For this purpose, LPS active fractions were pooled and dialyzed (cut off: $12.000 \mathrm{MW}$ ) for $24 \mathrm{~h}$ at $4{ }^{\circ} \mathrm{C}$. The dialyzed extract was then lyophilized in a Labconco freezedryer (FreeZone 61, Kansas City, Mo., U.S.A.), after dissolving 250 to $300 \mathrm{mg}$ dextran in it as a supporting agent. The enzyme prepared by this method and stored at $-18{ }^{\circ} \mathrm{C}$ maintained almost $70 \%$ of its activity for at least 2 mo (Mecitoğlu and Yemenicioğlu 2007). The activity of lyophilized LPS was determined before each film preparation.

\section{Preparation of alginate films}

The alginate films were prepared according to the method given by Mecitoğlu and Yemenicioğlu (2007). Briefly, 0.2 to $0.6 \mathrm{mg}$ of lyophilized LPS preparation were dissolved per gram of $2 \%(\mathrm{w} / \mathrm{v})$ alginic acid solution by mixing slowly with a magnetic stirrer. The concentration of LPS preparation was selected carefully to set enzyme activity of all films at $70 \mathrm{nmol} \mathrm{ABTS} / \mathrm{min} / \mathrm{cm}^{2}$. Ten-gram portions of this solution were then spread onto glass Petri dishes $(9.5 \mathrm{~cm}$ in diameter). The Petri dishes were covered with a tent and dried at room temperature for $3 \mathrm{~d}$. To cross-link the dried films, $0.8 \mathrm{~mL}$ of $0.3 \mathrm{M} \mathrm{CaCl}_{2}$ was pipetted onto the Petri dishes. The films were peeled from the Petri dishes and washed with $10 \mathrm{~mL}$ sterile deionized water for $15 \mathrm{~s}$ to remove the excessive $\mathrm{CaCl}_{2}$, which causes precipitations during LPS activity measurements. The average thickness of a cross-linked and dried control and LPS incorporated films prepared by this method was determined by a scanning electron microscope (Philips XL 30S FEG, FEI Co., Eindhoven, The Netherlands) as 13.05 and $18.87 \mu \mathrm{m}$, respectively.

\section{Determination of soluble enzyme activity in LPS preparations}

The soluble LPS activity of enzyme preparations was determined spectrophotometrically by using a Shimadzu (Model 2450, Tokyo, Japan) spectrophotometer equipped with a constant temperature cell holder working at $30{ }^{\circ} \mathrm{C}$. Before activity determination, the lyophilized LPS was dissolved in distilled water. The reaction mixture consisted of $2.3 \mathrm{~mL}$ of $0.65 \mathrm{mM}$ ABTS prepared in $0.1 \mathrm{M}$ sodium phosphate buffer at $\mathrm{pH} 6,0.1 \mathrm{~mL}$ of enzyme solution, and $0.1 \mathrm{~mL}$ of $0.2 \mathrm{mM} \mathrm{H}_{2} \mathrm{O}_{2}$ solution. All components of the reaction mixture were brought to $30{ }^{\circ} \mathrm{C}$ before mixing. The absorbance was monitored at $412 \mathrm{~nm}$ for $5 \mathrm{~min}$. The enzyme activity was calculated from the slope of the initial portion of absorbance against time curve and expressed as amount of ABTS oxidized per minute per milligram of LPS preparation. The molar extinction coefficient of ABTS at $412 \mathrm{~nm}$ was 32400 per M/cm (Touch and others 2004). The average of the 3 measurements was used to calculate enzyme activity.

\section{Determination of soluble or bound LPS activity in films}

To determine the soluble LPS activity in the films, cross-linked alginate films incorporated with LPS were placed into glass Petri dishes containing $50 \mathrm{~mL}$ of cold deionized water $\left(4^{\circ} \mathrm{C}\right)$. The Petri dishes, covered with parafilm to prevent evaporation, were incubated at $4{ }^{\circ} \mathrm{C}$ for $24 \mathrm{~h}$ and stirred at $200 \mathrm{rpm}$ using a magnetic stirrer. The deionized water was then tested for residual enzyme activity. To increase the sensitivity of the enzyme activity test, the standard reaction mixture was changed to $2.2 \mathrm{~mL}$ of $0.65 \mathrm{mM}$ ABTS prepared in $0.1 \mathrm{M}$ sodium phosphate buffer at $\mathrm{pH} 6,0.2 \mathrm{~mL}$ of deionized water obtained from the test medium, and $0.1 \mathrm{~mL}$ of $0.4 \mathrm{mM} \mathrm{H}_{2} \mathrm{O}_{2}$ solution. However, in this study, no soluble LPS activity was determined in the alginate films.

To determine the activity of bound LPS in the alginate films, the cross-linked and washed $(15 \mathrm{~s}$ in $10 \mathrm{~mL}$ sterile deionized water) films were carefully halved with a clean razor. A film half was then placed into a glass Petri dish containing $23 \mathrm{~mL}$ of $0.65 \mathrm{mM}$ ABTS solution prepared in $0.1 \mathrm{M}$ sodium phosphate buffer at $\mathrm{pH} 6.0$ and $2 \mathrm{~mL}$ of $0.2,0.4$, or $0.8 \mathrm{mM} \mathrm{H}_{2} \mathrm{O}_{2}$ solution. The solutions were brought to $30{ }^{\circ} \mathrm{C}$ before placing the film into the Petri dishes. The Petri dishes were incubated at $30{ }^{\circ} \mathrm{C}$ under continuous stirring at $200 \mathrm{rpm}$ with a magnetic stirrer. The activity monitored by measuring the reaction mixture absorbance at $412 \mathrm{~nm}$ at different time intervals was determined from the slope of the initial linear portion of absorbance against time curve. The measurements were performed for the remaining half of the films and the average of 2 measurements was considered to calculate the activity. The enzyme activity was expressed as amount of ABTS oxidized per minute per square centimeter of the films.

\section{Antimicrobial activity of LPS system}

The bacterial strains, E. coli (NRRL B-3008), L. innocua (NRRL B-33314), and $P$. fluorescens (NRRL B-253), were maintained in nutrient broth containing $15 \%$ glycerol at $-80^{\circ} \mathrm{C}$ prior to the analyses. During activation of bacteria, E. coli and L. innocua were incubated using nutrient broth at $37^{\circ} \mathrm{C}$ for 16 to $18 \mathrm{~h}$, whereas $P$. fluorescens in nutrient broth was incubated at $26{ }^{\circ} \mathrm{C}$ for 16 to $18 \mathrm{~h}$. All bacteria reached the stationary phase under these conditions (data not shown).

The cross-linked alginate films incorporated with LPS (or lacking LPS for controls) were prepared for the test by washing with $25-\mathrm{mL}$ sterile deionized water for $15 \mathrm{~s}$ and cutting into $1.3-\mathrm{cm}$ diameter discs using a sterilized cork borer under aseptic conditions. The discs were placed into test tubes containing nutrient broth (3 mL), 1 of the cultures $(0.5 \mathrm{~mL}), 1,2$, or $4 \mathrm{mM} \mathrm{KSCN}(0.1 \mathrm{~mL})$, and $0.2,0.4$, or $0.8 \mathrm{mM} \mathrm{H}_{2} \mathrm{O}_{2}(0.1 \mathrm{~mL})$. Sterile distilled water $(0.1 \mathrm{~mL})$ was used instead of $\mathrm{KSCN}$ and/or $\mathrm{H}_{2} \mathrm{O}_{2}$ in some reaction mixtures lacking these reactants. The initial number of different bacteria in reaction mixtures changed between 3 and $4 \log _{10}$ $\mathrm{CFU} / \mathrm{mL}$. After preparation of reaction mixtures, tubes inoculated with E. coli or L. innocua were incubated at $37^{\circ} \mathrm{C}$ for $24 \mathrm{~h}$, whereas tubes inoculated with $P$. fluorescens were incubated at $26{ }^{\circ} \mathrm{C}$ for $24 \mathrm{~h}$. The microbial growth in the tubes was enumerated on 
nutrient agar by taking samples from reaction mixtures at 0,6 , and $24 \mathrm{~h}$ of incubation by using pour-plate method. The duplicate plates for each dilution were incubated at $37^{\circ} \mathrm{C}$ for $24 \mathrm{~h}$ for E. coli, at $37^{\circ} \mathrm{C}$ for $48 \mathrm{~h}$ for L. innocua, and at $26^{\circ} \mathrm{C}$ for $48 \mathrm{~h}$ for P. fluorescens. The microbial counts were calculated as CFU per milliliter $(\mathrm{N})$. The results of antimicrobial tests were expressed by plotting $\log \mathrm{N}_{\mathrm{t}} / \mathrm{N}_{\mathrm{o}}$ against incubation period of reaction mixtures (hours).

\section{Data analysis}

Statistical analysis was performed using MINITAB $^{\mathrm{B}}$ release 13 (Minitab Inc., State College, Pa., U.S.A.). The data for LPS activity and the changes in microbial counts during $24 \mathrm{~h}$ of incubation were analyzed using analysis of variance (ANOVA) and Tukey's HSD significance test. Significance was accepted at $P<0.05$.

\section{Results and Discussion}

\section{LPS activity and concentrations of other components of antimicrobial system}

In this study, the lyophilized LPS was incorporated into alginate films to exploit a naturally occurring antimicrobial mechanism. The results of our previous findings showed tight binding of lyophilized LPS in alginate films unless its incorporated concentration exceeded $700 \mu \mathrm{g} / \mathrm{cm}^{2}$ (Mecitoğlu and Yemenicioğlu 2007). Thus, the level of LPS incorporated was maintained below $600 \mu \mathrm{g} / \mathrm{cm}^{2}$ to prevent its solubilization from the films. The binding of LPS to alginate films and lack of its soluble form in films was also confirmed in this study by conducting soluble enzyme activity measurements following incubation of films in distilled water at $4{ }^{\circ} \mathrm{C}$ for $24 \mathrm{~h}$. The polymeric chains of alginate can form negative charges by ionization of their carboxylic acid groups and LPS has a very high pI value (9.6). Thus, it is proposed that the positive charges of LPS formed under close to neutral conditions of filmmaking caused binding of the enzyme to the film matrix. The LPS was prepared with dextran. Thus, the H-binding of this polysaccharide to LPS and alginate could also make a contribution to the binding of enzyme (Mecitoğlu and Yemenicioğlu 2007).

The bound and retained activity in alginate films incorporated with $70 \mathrm{nmol} \mathrm{ABTS} / \mathrm{min} / \mathrm{cm}^{2}$ LPS was determined at $\mathrm{H}_{2} \mathrm{O}_{2}$ concentrations of $0.2,0.4$, or $0.8 \mathrm{mM}$ (Figure 1). The results revealed that the activity of LPS did not change significantly $(P \geq 0.05)$ at the studied concentration range of $\mathrm{H}_{2} \mathrm{O}_{2}$. However, a slight reduction in average enzyme activity at 0.4 and $0.8 \mathrm{mM}$ suggested a possible inhibitory effect of $\mathrm{H}_{2} \mathrm{O}_{2}$ on LPS. This result complies with that of Fonteh and others (2005) who reported substrate inhibitory activity of $\mathrm{H}_{2} \mathrm{O}_{2}$ on LPS above $0.2 \mathrm{mM}$ concentration. In the literature, the $\mathrm{H}_{2} \mathrm{O}_{2}$ concentrations used to investigate antimicrobial activity of LPS changed between 0.25 and $0.5 \mathrm{mM}$ (Zapico and others 1998; Jacob and others 2000; Garcia-Graells and others 2003). It seems

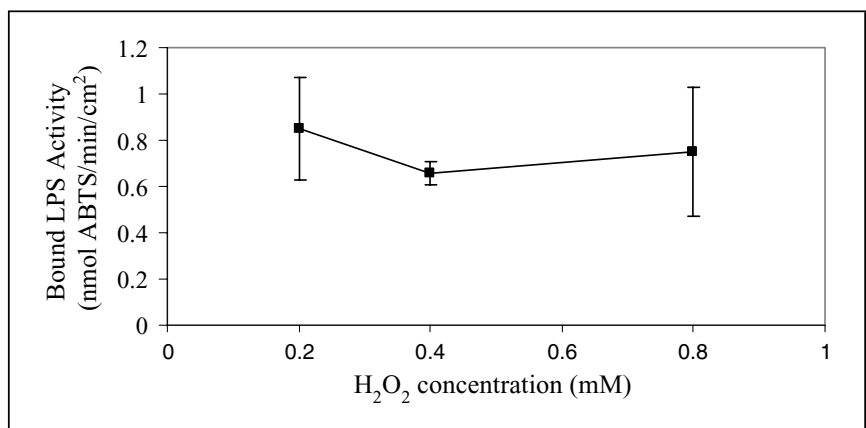

Figure 1 - Immobilized LPS activity of cross-linked alginate films at different $\mathrm{H}_{2} \mathrm{O}_{2}$ concentrations. that the higher concentrations of $\mathrm{H}_{2} \mathrm{O}_{2}$ have been preferred due to the rapid degradation of $\mathrm{H}_{2} \mathrm{O}_{2}$ by the LPS used in tests and other $\mathrm{H}_{2} \mathrm{O}_{2}$ decomposing factors such as bacterial enzyme systems and reducing compounds in the test medium.

The range of KSCN concentrations applied in this study ( 1 and $4 \mathrm{mM}$ ) was selected from 8 different concentrations between 0.1 and $40 \mathrm{mM}$ with a preliminary test by considering minimum amounts of this chemical necessary for consumption of $>90 \%$ of $0.4 \mathrm{mM} \mathrm{H}_{2} \mathrm{O}_{2}\left(\mathrm{H}_{2} \mathrm{O}_{2}\right.$ concentration was determined by semiquantitative test papers, Merck, Darmstadt, Germany) in a reaction mixture containing LPS incorporated discs and E. coli culture within $24 \mathrm{~h}$ of incubation at $37^{\circ} \mathrm{C}$.

\section{Antimicrobial activity of LPS system}

The antimicrobial activity of LPS system employed in presence of $0.2,0.4$, or $0.8 \mathrm{mM} \mathrm{H}_{2} \mathrm{O}_{2}$ and $4 \mathrm{mM} \mathrm{KSCN}$ was seen in Figure 2A. The LPS system caused low inhibitory effect on growth of $E$. coli in presence of $0.2 \mathrm{mM} \mathrm{H}_{2} \mathrm{O}_{2}$ and $4 \mathrm{mM} \mathrm{KSCN}$. However, a significant inhibitory effect on this bacterium was observed at $6 \mathrm{~h}$ of incubation when $\mathrm{H}_{2} \mathrm{O}_{2}$ was increased to 0.4 or $0.8 \mathrm{mM}$ in presence of $4 \mathrm{mM}$ KSCN. In all reaction mixtures, the inhibitory effect of LPS system on $E$. coli exhausted when incubation periods were extended to $24 \mathrm{~h}$. Figure 2B shows the antimicrobial effect of LPS system on $E$. coli in presence of $0.2 \mathrm{mM} \mathrm{H}_{2} \mathrm{O}_{2}$ and 1 or $2 \mathrm{mM} \mathrm{KSCN}$. Under these conditions, the LPS system did not show a considerable antimicrobial activity on E. coli, and interestingly it became more effective with $1 \mathrm{mM}$ KSCN than $2 \mathrm{mM} \mathrm{KSCN}$ at the end of 6 -h incubation. It seems that the low concentration of $\mathrm{H}_{2} \mathrm{O}_{2}$ and $\mathrm{KSCN}$ controlled the rate of enzymatic transformation and prevented the rapid exhaustion of formed antimicrobial metabolites.

Figure 3A shows the antimicrobial activity of LPS system on $L$. innocua at 0.2 to $0.8 \mathrm{mM} \mathrm{H}_{2} \mathrm{O}_{2}$ and $4 \mathrm{mM} \mathrm{KSCN}$ concentrations. Similar to results obtained for $E$. coli, the LPS system was not very effective on L. innocua in presence of $0.2 \mathrm{mM} \mathrm{H}_{2} \mathrm{O}_{2}$ and $4 \mathrm{mM}$ KSCN. The LPS system prevented the growth of $L$. innocua for a 6$\mathrm{h}$ period at $0.4 \mathrm{mM} \mathrm{H}_{2} \mathrm{O}_{2}$ and $4 \mathrm{mM} \mathrm{KSCN}$ concentrations, but the growth of bacteria under these conditions could not be prevented at the end of $24 \mathrm{~h}$ of incubation. The elevation of $\mathrm{H}_{2} \mathrm{O}_{2}$ concentration to $0.8 \mathrm{mM}$ at the same KSCN concentration became very effective on inhibition of L. innocua by reducing and keeping its counts below the initial counts for a $24 \mathrm{~h}$ period. This result clearly showed the greater inhibitory effect of LPS system on L. innocua than $E$. coli at highest $\mathrm{H}_{2} \mathrm{O}_{2}$ and $\mathrm{KSCN}$ concentrations. On the other hand, in presence of $0.2 \mathrm{mM} \mathrm{H}_{2} \mathrm{O}_{2}$ and 1 or $2 \mathrm{mM} \mathrm{KSCN}$, the LPS system showed low inhibitory effect on growth of L. innocua (Figure 3B).

The effect of LPS system on $P$. fluorescens was given in Figure 4A. The growth of $P$. fluorescens was inhibited by the LPS system for a 6 - $\mathrm{h}$ incubation period in presence of $0.2,0.4$, or $0.8 \mathrm{mM} \mathrm{H}_{2} \mathrm{O}_{2}$ and $4 \mathrm{mM}$ KSCN. The LPS system employed in presence of $0.2 \mathrm{mM} \mathrm{H}_{2} \mathrm{O}_{2}$ and $4 \mathrm{mM}$ KSCN could not prevent growth of $P$. fluorescens at the end of $24 \mathrm{~h}$. However, LPS system employed in presence of 0.4 or $0.8 \mathrm{mM} \mathrm{H}_{2} \mathrm{O}_{2}$ at the same KSCN concentration delayed and prevented the growth of $P$. fluorescens at the end of $24 \mathrm{~h}$, respectively. In presence of $0.2 \mathrm{mM} \mathrm{H}_{2} \mathrm{O}_{2}$ and 1 or $2 \mathrm{mM} \mathrm{KSCN}$, the LPS system showed an inhibitory effect and maintained the $P$. fluorescens counts below initial count for a 6 -h period (Figure 4B). However, at these concentrations, the effect of LPS system exhausted and it showed no antimicrobial activity at the end of $24 \mathrm{~h}$. On the other hand, it is interesting to note that the counts of $P$. fluorescens in reaction mixtures lacking $\mathrm{H}_{2} \mathrm{O}_{2}$ but containing other components of reaction mixtures were higher than those of the control and reaction mixture containing only LPS. This occurred due to the activatory effect of KSCN on P. fluorescens and it was confirmed by repeated 
tests with same reaction mixtures (data not given). Thus, it is clear that the use of LPS system against this bacterium needs application of high $\mathrm{H}_{2} \mathrm{O}_{2}$ concentrations to prevent excessive amounts of untransformed KSCN.
In the literature, there are very few reports related to use of LPS system in food antimicrobial packaging. The enzyme system was first incorporated into whey protein films by Min and others (2005a). These researchers supported the

\section{A}

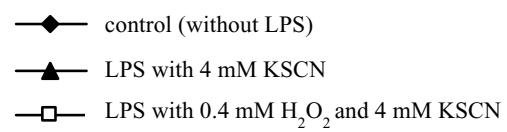

\section{Reaction mixtures}
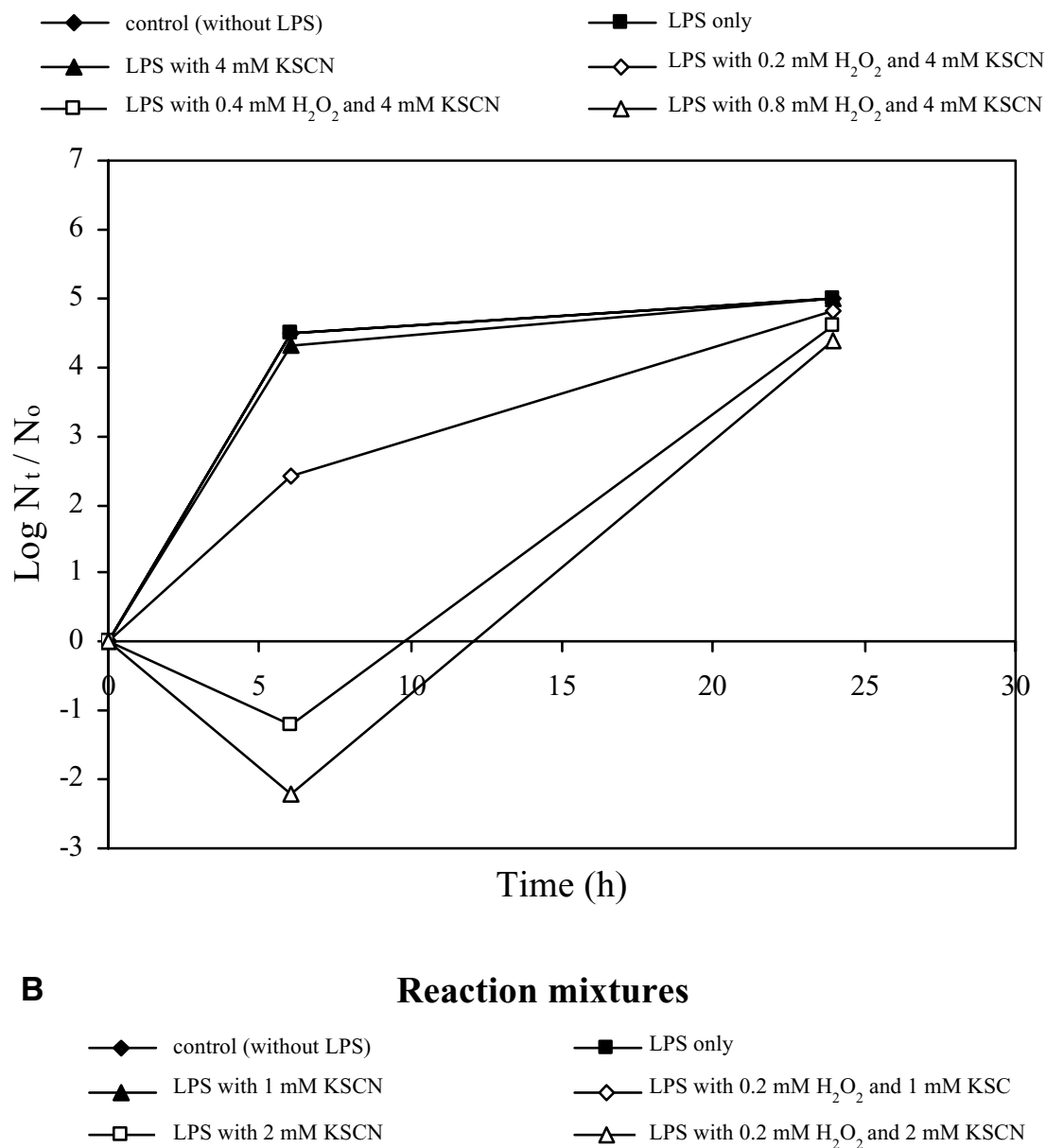

\section{Reaction mixtures}
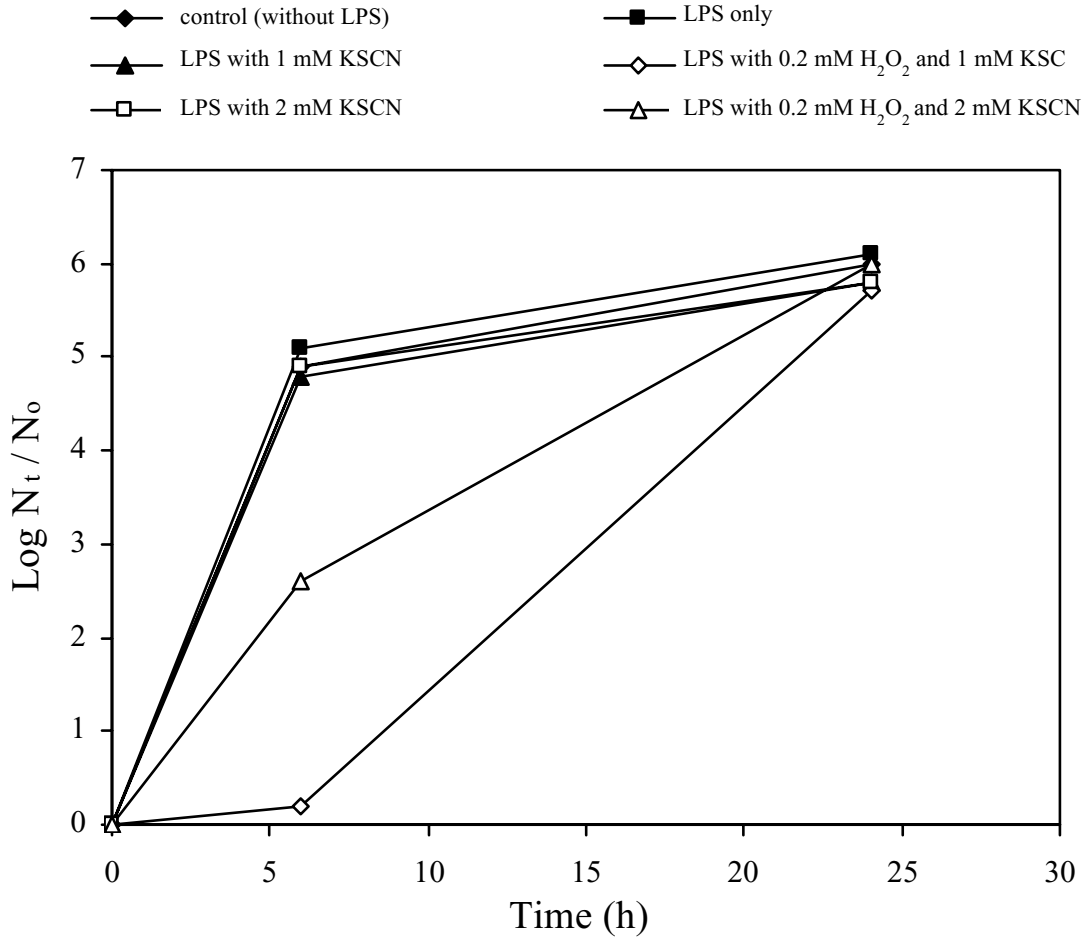

Time (h)
Figure 2- Antimicrobial effect of LPS incorporated alginate films on $E$. coli in reaction mixtures having different $\mathrm{H}_{2} \mathrm{O}_{2}$ (A) and KSCN (B)

concentrations (in both Figure $2 A$ and 2B, statistically significant

differences were observed regarding the incubation time effect $[P<0.05]$, except between 0 and $6 \mathrm{~h}$ of

incubation for reaction mixture shown with legend of $-\diamond-$ in B). 
lactoperoxidase- $\mathrm{KSCN}-\mathrm{H}_{2} \mathrm{O}_{2}$ system with glucose oxidase-glucose system to generate additional $\mathrm{H}_{2} \mathrm{O}_{2}$ for the LPS. The LPS system was then activated to form the antimicrobial metabolites and the reaction mixture was incorporated into whey protein isolate films. These films completely inhibited S. enterica and E. coli $\mathrm{O} 157: \mathrm{H} 7$, inoculated onto agar either before placing the film disc or after placing the film discs. It was also reported in another study by the same research group that the whey protein isolate films incorporated with LPS metabolites were also effective on L. monocytogenes and the developed system successfully extended the shelf life of smoked refrigerated salmon (Min and others 2005b).

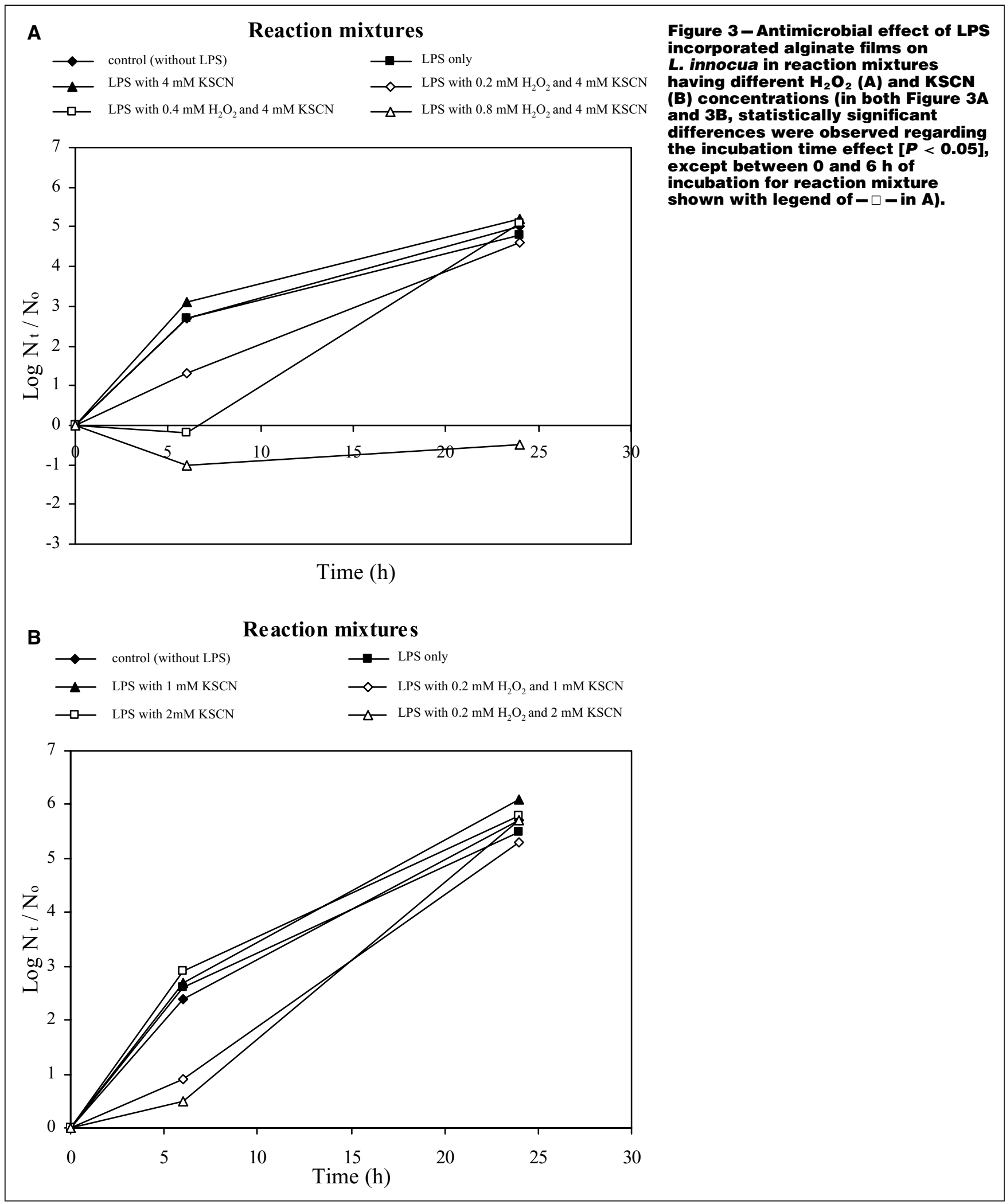




\section{Conclusions}

$\mathrm{T}$ he antimicrobial system formed by LPS incorporated alginate films, KSCN and $\mathrm{H}_{2} \mathrm{O}_{2}$ showed antimicrobial activity on different tested bacteria. The decreasing order of the resistance of bacteria to LPS system at the studied conditions is as follows: E. coli, L. innocua, and P. fluorescens. The duration of antimicrobial effect of LPS system depends on activity of enzyme and initial concen- trations of $\mathrm{H}_{2} \mathrm{O}_{2}$ and KSCN. During antimicrobial tests, the LPS has been employed at high incubation temperatures necessary for the bacterial growth, but this accelerated the enzyme activity and formation and degradation of reactive antimicrobial metabolites. Thus, the duration of antimicrobial effect of the developed system would be extended when the alginate films will be applied to refrigerated foods. Most of the patented applications of alginate
A

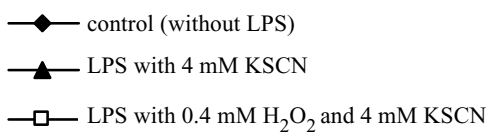

$\longrightarrow$ LPS only

$\checkmark$ LPS with $0.2 \mathrm{mM} \mathrm{H}_{2} \mathrm{O}_{2}$ and $4 \mathrm{mM} \mathrm{KSCN}$

$\triangle$ LPS with $0.8 \mathrm{mM} \mathrm{H}_{2} \mathrm{O}_{2}$ and $4 \mathrm{mM} \mathrm{KSCN}$

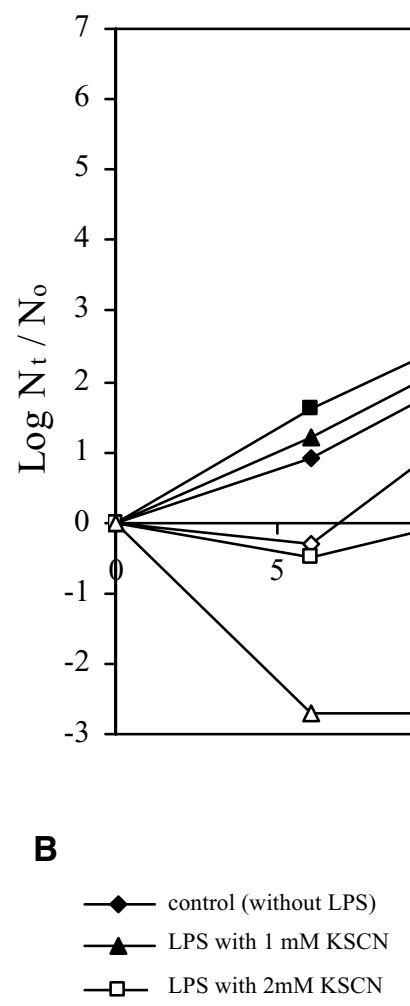

6

$\square$ LPS with $2 \mathrm{mM} \mathrm{KSCN}$

\section{Reaction mixtures}

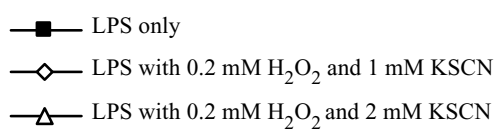

$\triangle \Delta$ LPS with $0.2 \mathrm{mM} \mathrm{H}_{2} \mathrm{O}_{2}$ and $2 \mathrm{mM} \mathrm{KSCN}$

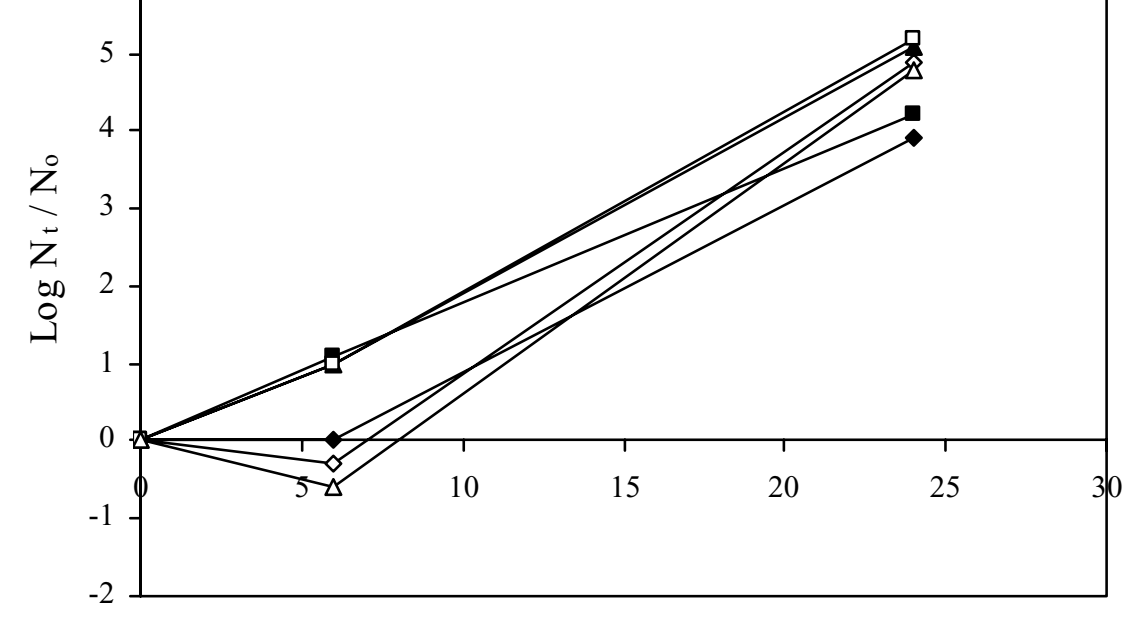

Time (h)
Figure 4-Antimicrobial effect of LPS incorporated alginate films on $P$. fluorescens in reaction mixtures having different $\mathrm{H}_{2} \mathrm{O}_{2}$ (A) and KSCN (B) concentrations (in both Figure 4A and $4 B$, statistically significant differences were observed regarding the incubation time effect $[P<0.05]$, except between 0 and $6 \mathrm{~h}$ of incubation for reaction mixtures shown with legends of $-\diamond-$ in $A,-\diamond-$ and $-\diamond-$ in $B$, and between 6 and $24 \mathrm{~h}$ of incubation for reaction mixture shown with legend of $-\Delta-$ in A). 
films have been developed for coating of meat, poultry, and seafood (Lindstrom and others 1992). Thus, the LPS incorporated antimicrobial films have a good potential to find food applications. Further studies are needed to test the LPS incorporated edible films in real food systems.

\section{Acknowledgments}

This research was supported by the Scientific and Technical Research Council of Turkey (TÜBİTAK, project nr 104M386) and the Research Fund of İzmir Inst. of Technology (project nr 2005-IYTE40).

\section{References}

Cagri A, Ustunol Z, Ryser ET. 2002. Inhibition of three pathogens on bologna and summer sausage using antimicrobial edible films. J Food Sci 67:2317-24.

Dean M, Zottola EA. 1996. Use of nisin in ice cream and effect on the survival of Liste ria monocytogenes. J Food Prot 59:476-80.

Delves-Broughton J, Blackburn RJ, Evans P, Hugenholtz J. 1998. Use of bacteriocinogenic lactic acid bacteria to inhibit spontaneous nisin-resistant mutants of Listeria monocytogenes Scott A. J Appl Microbiol 85:657-63.

Garcia-Graells C, Van Opstal I, Vanmuysen SCM, Michiels CW. 2003. The lactoperoxidase system increases efficacy of high-pressure inactivation of foodborne bacteria. Int J Food Microbiol 81:211-21.

Elliot RM, McLay JC, Kennedy MJ, Simmonds RS. 2004. Inhibition of foodborne bacteria by the lactoperoxidase system in a beef cube system. Int J Food Microbiol 91:7381.

Eswaranandam S, Hettiarachchy NS, Johnson MG. 2004. Antimicrobial activity of citric, lactic, malic, or tartaric acids and nisin-incorporated soy protein film against Listeria monocytogenes, Escherichia coli $\mathrm{O} 157: \mathrm{H7}$, and Salmonella gaminara. J Food Sci 69:FMS79-84.

Fonteh FA, Grandison AS, Lewis MJ. 2005. Factors affecting lactoperoxidase activity. Int J Dairy Technol 58:233-6.

Han JH. 2000. Antimicrobial food packaging. Food Technol 54:56-65.

Hoover DG, Steenson LR. 1993. Bacteriocins of lactic acid bacteria. San Diego, Calif: Academic Press. 275 p.

Jacob BM, Antony E, Sreekumar B, Haridas M. 2000. Thiocyanate mediated antifungal and antibacterial property of goat milk lactoperoxidase. Life Sci 66:2433-9.

Kennedy M, O’Rourke A-L, McLay J, Simmonds R. 2000. Use of a ground beef model to assess the effect of the lactoperoxidase system on the growth of Escherichia coli
O157:H7, Listeria monocytogenes and Staphylococcus aureus in red meat. Int J Food Microbiol 57:147-58.

Kussendrager KD, van Hooijdonk ACM. 2000. Lactoperoxidase: physico-chemical properties, occurrence, mechanism of action and applications. Br J Nutr 84:S1925.

Lindstrom TR, Morimoto K, Cante CJ. 1992. Edible films and coatings. In Hui YH, editor. Encyclopedia of Food Science and Technology, Vol 2. New York: John Wiley and Sons, Inc., p 59-663.

Mecitoğlu C, Yemenicioğlu A. 2007. Partial purification and preparation of bovine lactoperoxidase and characterization of kinetic properties of its immobilized form incorporated into cross-linked alginate films. Food Chem 104:726-33.

Min S, Krochta JM. 2005. Inhibition of Penicillium commune by edible whey protein films incorporating lactoferrin, lactoferrin hydrolysate, and lactoperoxidase systems. J Food Sci 70:M87-94.

Min S, Harris LJ, Krochta JM. 2005a. Antimicrobial effects of lactoferrin, lysozyme, and the lactoperoxidase system and edible whey protein films incorporating the lactoperoxidase system against Salmonella enterica and Escherichia coli O157:H7. J Food Sci 70:M332-8.

Min S, Harris LJ, Krochta JM. 2005b. Listeria monocytogenes inhibition by whey protein films and coatings incorporating the lactoperoxidase system. J Food Sci 70:M317-24.

Pakkanen R, Aalto J. 1997. Growth factors and antimicrobial factors of bovine colostrums. Int Dairy J 7:285-97.

Quattara B, Simard RE, Piette G, Begin A, Holley RA. 2000. Inhibition of surface spoilage bacteria in processed meats by application of antimicrobial films prepared with chitosan. Int J Food Microbiol 62:139-48.

Reiter B, Harnulv G. 1984. Lactoperoxidase antibacterial system: natural occurrence, biological functions and practical applications. J Food Prot 47:724-32.

Seifu E, Buys EM, Donkin EF, Petzer I-M. 2004. Antibacterial activity of the lactoperoxidase system against food-borne pathogens in Saanen and South African Indegenous goat milk. Food Cont 15:447-52.

Seifu E, Buys EM, Donkin EF. 2005. Significance of the lactoperoxidase system in the dairy industry and its potential applications: a review. Trends Food Sci Technol 16:1-18.

Touch V, Hayakawa S, Yamada S, Kaneko S. 2004. Effects of a lactopeoxidasethiocyanate-hydrogen peroxide system on Salmonella enteritidis in animal or vegetable foods. Int J Food Microbiol 93:175-83.

Wolfson LM, Sumner SS. 1993. Antimicrobial activity of the lactoperoxidase system: a review. J Food Prot 56:887-92.

Ye X, Yoshida S, Ng TB. 2000. Isolation of lactoperoxidase, lactoferrin, $\alpha$-lactalbumin $\beta$-lactoglobulin A from bovine rennet whey using ion exchange chromatography. Int J Biochem Cell Biol 32:1143-50.

Zapico P, Medina M, Gaya P, Nunez M. 1998. Synergistic effect of nisin and the lactoperoxidase system on Listeria monocytogenes in skim milk. Int J Food Microbiol 40:35-42. 